\title{
Dermatoscopy of Verrucous Pigmented Lesions is Essential for Choosing the Appropriate Treatment
}

\author{
VIRGINIA CHIȚU ${ }^{1,3}$, SABINA ZURAC ${ }^{2,3}$, ALINA E. CIPI $^{4}$ \\ ${ }^{1}$ First Department of Dermatology, "Colentina" Clinical Hospital, Bucharest, Romania \\ ${ }^{2}$ Department of Pathology, "Colentina" Clinical Hospital, Bucharest, Romania \\ "Carol Davila" University of Medicine and Pharmacy, Bucharest, Romania \\ 4،"Regina Maria" Private Healthcare Network, Bucharest, Romania
}

\begin{abstract}
Dermatoscopy, as a noninvasive rapid method, which allows the viewing of melanin in the epidermis and papillary dermis, has an important role in diagnosis of the pigmented lesions localized on skin, mucous membrane, scalp and nails. The term of verrucous pigmented lesions includes a series of non-melanocytic and melanocytic, benign and malignant lesions. Among these, the most frequent is the seborrheic keratosis, a common epidermal tumor, affecting the sun exposed areas of adult. At the other end of the spectrum regarding the frequency is the seborrheic keratosis-like melanoma, whose underdiagnosis has a serious impact on the patient's life. In this work we present the clinical and dermoscopical aspects of three cases of verrucous pigmented lesions (two seborrheic keratoses and one seborrheic keratosis-like melanoma) that determined the diagnostic algorithm as well as the therapeutic approach. The above-presented cases underline the importance of dermatoscopy to determine the malignant potential of the pigmented lesions, the final appropriate treatment being possible after the histopathologic confirmation.
\end{abstract}

Key words: dermatoscopy, dermoscopy, nevus, melanoma, seborrheic keratosis, pigmented.

\section{INTRODUCTION}

Nowadays, dermatoscopy became an important technique for the assessment of the pigmented lesions localized on the skin, mucous membrane, scalp and nails, permitting to establish the melanocytic and nonmelanocytic nature of the lesions and also to distinguish between benign and malignant lesions [1-3].

The frequent use of dermatoscopy allows the early detection of melanoma, when it is clinically difficult to differentiate from benign lesions and reduces the advanced melanoma cases, with impact on prognosis and medico-legal implications $[1,4]$.

Under the term of verrucous pigmented lesions can be included benign lesions like seborrheic keratosis, congenital and acquired melanocytic nevi, pigmented actinic keratosis, but also malignant lesions like melanoma.

Seborrheic keratosis is one of the most common benign tumors of the skin, presenting a variety of clinical, dermatoscopic and histological appearances, still having an unknown etiopathology $[5,6]$. This common lesion is usually found on sun exposed areas of the middle aged adult and it differs from melanocytic nevi and melanoma by its waxy and dull aspect, with horny plugs on the surface being easily removed. Besides these common types of seborrheic keratosis which can be easily recognized by clinical and dermatoscopic appearance, irritated and deeply pigmented seborrheic keratosis can be confused with verrucous melanocytic nevi and, even with melanoma [7, 8]. These types of lesions will require excisional biopsy for the confirmation of the diagnosis, in order to prevent a wide and unnecessary local excision, reducing the cost and the patient's discomfort $[6,9]$.

Congenital and papillomatous melanocytic nevi can develop keratin plugs inside the epidermal invaginations and follicular openings, with variate sizes and colours ranging from yellow to black depending also on the level of melanin [1]. These nevi can be mistaken for seborrheic keratosis when the masses of keratin are abundant and the level of melanin is low.

Melanoma - the most aggressive skin cancer, responsible for $79 \%$ of the mortality by skin cancer, is renowned by the multitude of clinical and dermatoscopic aspects, especially in its early stages $[1,10,11]$. The verucous melanoma is an extremely rare type of melanoma, very similar to seborrheic keratosis, a very serious confusion, imposing the recommendation of the histopathological examination of all the seborrheic keratosis that do not show all the specific clinical and dermatoscopic criteria for 
seborrheic keratoses or have at least a common feature with the melanoma $[12,13]$. The verrucous melanoma can occur de novo or this verrucous aspect can develop during the evolution of any of the four important histopathological types: superficial spreading melanoma, nodular melanoma, lentigo maligna melanoma, acral lentiginous melanoma [14].

\section{CASE 1}

A 27 years old woman, came to our clinic recently after pregnancy for an itching, pink to dark

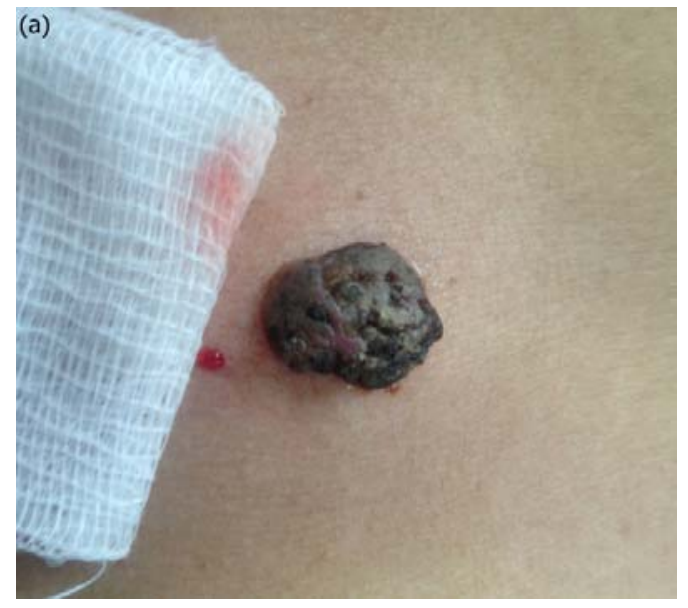

brown nodular lesion on the abdomen which changed during the last months (Fig. 1a). She related that the lesion was present since childhood. The dermatoscopic evaluation showed multiple yellowish to brown-grey masses of keratin, numerous milialike and comedo-like structures, comma vessels (Fig. 1b). The age and the history of the patient, the localisation and the size of the lesion conducted for a verrucous melanocytic lesion, the differential diagnosis being made with an irritated seborrheic keratosis. A surgical excision with a $2 \mathrm{~mm}$ border was performed and the histopathological exam was consistent with a seborrheic keratosis (Fig. 1c).
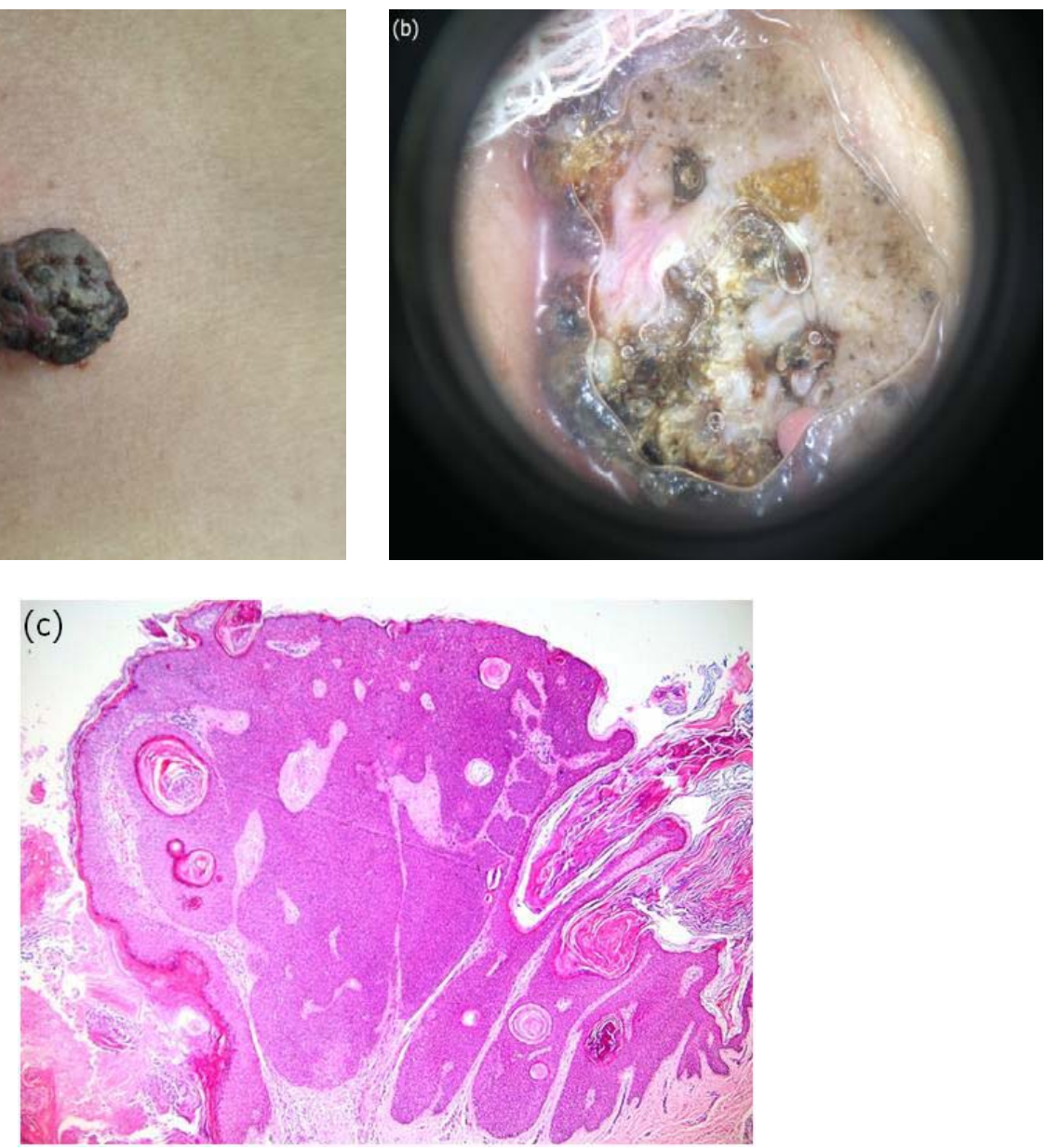

Figure 1. (a) Clinical presentation: large pigmented nodule, (b) Dermoscopic image showed yellowish keratin masses, multiple comedo-like and milia-like structures, (c) Proliferation of basaloid cells with interspersed horn cysts filled with keratin. $\mathrm{HE} \times 40$.

\section{CASE 2}

A 62 years old woman, with a history of breast cancer, came to our clinic for a black-bluish, verrucous plaque, developed during the previous year on the left cheek (Fig. 2a), that she treated on her own with an ointment made of plants. After the clinical examination, a topical maltreated seborrheic keratosis or a hemangioma were suspected and less likely melanoma. Due to the verrucous surface, the first dermoscopic examination revealed only a homogeneous brown-grey pigmentation (Fig. 2b). After the mild removal of the scales, the second dermoscopic examination was performed and it revealed a blue-greyish coloration, covering most of the lesion, few irregular dark-brown dots and 
globules and a sharp border, except the portion between 10 and 12 o'clock where one could be noticed some faint regular brown lines (Fig. 2c). Melanoma could not be excluded after the second dermatoscopic examination, therefore an excisional biopsy was performed and the histopathological exam showed that the lesion was a melanoma with Breslow depth of $1.6 \mathrm{~mm}$ and Clark level II (Fig. 2d).
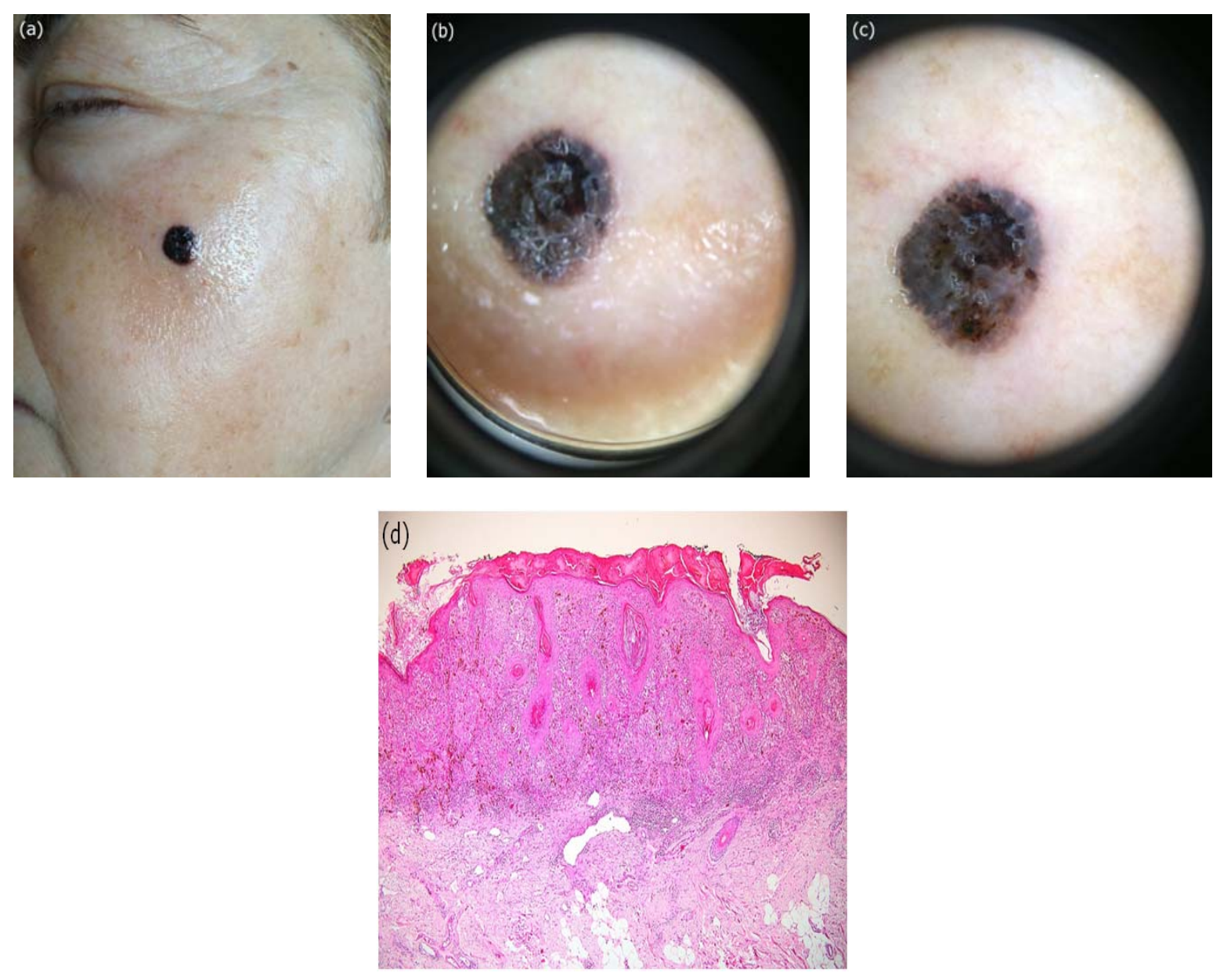

Figure 2. (a) Clinical photo, (b) The first dermatoscopic examination showed an intense pigmentation that occluded any underlying structures, (c) The second dermatoscopic examination revealed very subtle features of melanoma such as a few irregular black dots and globules and faint pseudopods between 10 and 12 o'clock, (d) Melanocytic proliferation with asymmetric silhouette; epidermal hyperplasia with superficial hyperortho and parakeratosis with small collection of eosinophilic liquid and neutrophils. Mild to moderate inflammatory infiltrate beneath the tumor. $\mathrm{HE} \times 40$.

\section{CASE 3}

A 57 years old woman presented to our department for a few years history of a moderately raised, irregular edge, pigmented plaque situated on the internal part of the right arm with a chromatic ranging from light brown to black (Fig. 3a). The clinical aspect was highly suggestive for superficial spreading melanoma.

The dermatoscopic examination revealed a grey-whitish coloration covering the $2 / 3$ of the lower part of the lesion and faint, brown, radial streaming at the left edge between 7 and 11 o'clock. We also noticed black irregular dots and globules and pigmented network remanents in the center (Fig. 3b).

The clinical and dermatoscopic diagnostic was consistent with the diagnosis of superficial spreading melanoma. The lesion was excised and the histopathological exam showed the diagnosis of seborrheic keratosis (Fig. 3c). The reevaluation of the dermatoscopic image (Fig. 3b) after knowing the histopathological diagnostic led to the following observations: the whole right edge of the lesion was well defined, the dots and the globules previously identified were, in fact, comedo-like structures, and the disorganized network was generated by the pseudolines. 

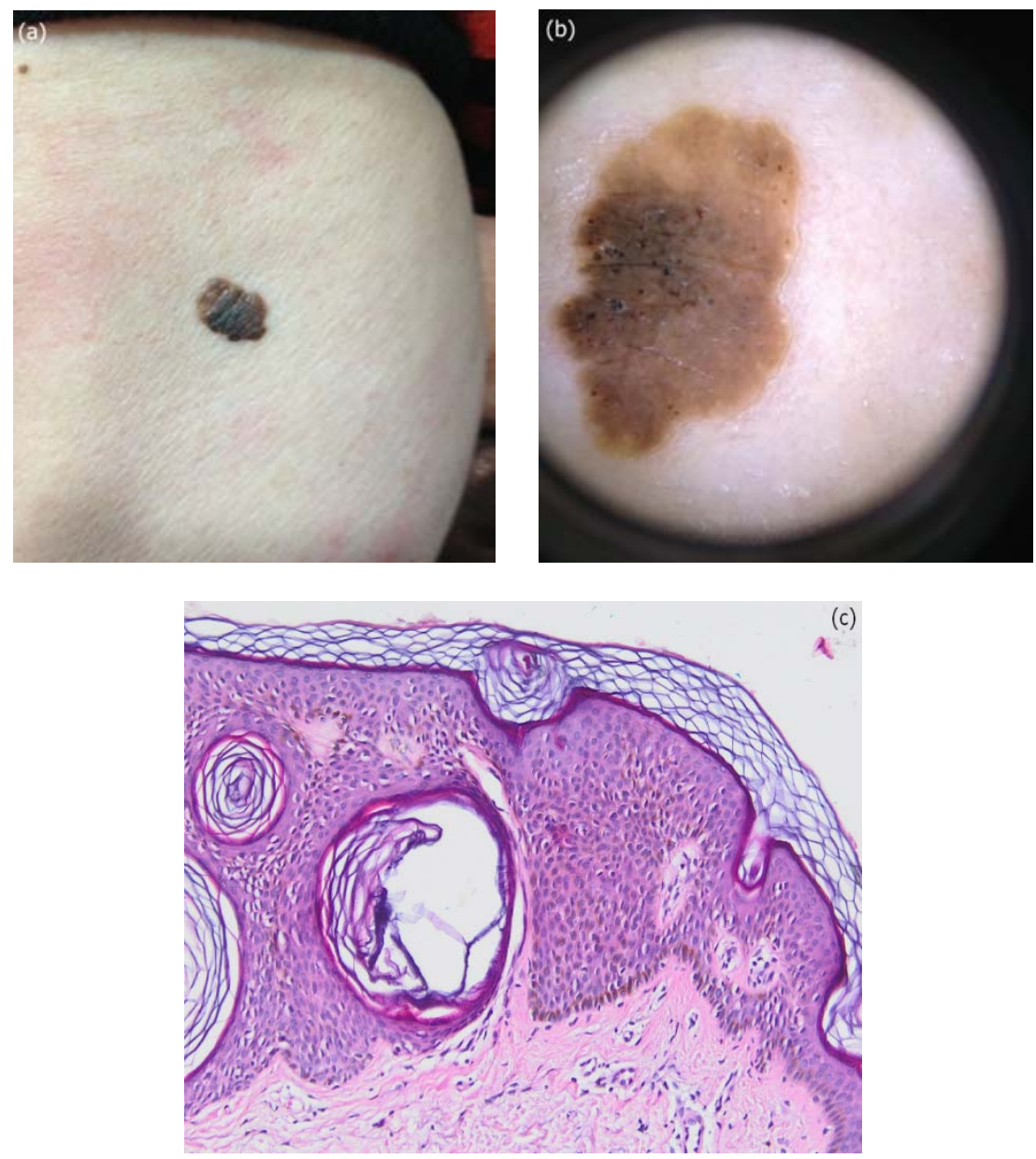

Figure 3. (a) Clinical appearance mimicked melanoma, (b) Dermatoscopic image presented specific criteria to seborrheic keratosis such as well-defined margins, milialike and comedo-like structures and pseudolines, (c) basaloid proliferation with keratin filled cysts and mild basal hyperpigmentation $\mathrm{HE} \times 200$.

\section{DISCUSSION}

Seborrheic keratosis being such a common lesion seen in the sun exposed areas of middle aged adults, it is often taken into account in the differential diagnosis of either benign or malignant melanocytic lesions, as it happened in the above described cases. The clinical data are essential for the accuracy of diagnosis, both from the positive and the negative point of view. In the first case, the age of the patient and wrongly appreciated history of the lesion by the patient, led to a first diagnosis of hypopigmented papillomatous nevus. The dermatoscopic image could be interpreted in this diagnosis because of the numerous comedo-like structures, most of them of small sizes being similar to the brown dots from the melanocytic nevi (Fig. 1b).

In the third case, the multitude of the clinical features of melanoma (asymmetry, presence of 3 colours, irregular border, tendency to change) led to a wrong interpretation of the dermatoscopic aspect. So, the comedo-like and pseudo-networklike structures specific for the seborrheic keratosis were wrongly interpreted as dots, globules and irregular pigmented network generated by melanocytes. Instead, the sharp border in the right half of the lesion, which should have risen the suspicion of a seborrheic keratosis, has been ignored (Fig. 3b). In the second case, the dermatoscopic examination showed only subtle criteria of melanoma, as a few irregular black dots and globules, but, on the other hand, there were no milia-like and comedo-like structures, specific for a seborrheic keratosis (Fig. 2c).

\section{CONCLUSIONS}

The dermatoscopic examination should be a compulsory stage in the diagnosis of the verrucous pigmented lesions, taking into account that among 
them, besides the common seborrheic keratosis, we can also find the verrucous melanoma, the congenital and the acquired melanocytic nevi. The lesions suspected of malignancy on dermatoscopy or whose nature can not be clearly established, must be surgically excised with a narrow border, in order to have a complete histopathological examination. In this way, the treatment performed will be appropriate, avoiding large excisions and even more important underdiagnosis and improper treatment of melanoma.

Acknowledgement. This paper was supported by the Sectoral Operational Programme Human Resources Development (SOP HRD), financed from the European Social Fund and by the Romanian Government under the contract POSDRU/159/1.5/ S/137390.

Dermatoscopia este o tehnică extrem de utilă în diagnosticarea leziunilor pigmentate cutaneo-mucoase, permițând identificarea leziunilor posibil maligne. Leziunile pigmentate verucoase necesită o evaluare atentă, deoarece alături de leziuni benigne precum keratozele seboreice, nevii melanocitari, includ şi melanomul verucos. In acest articol sunt prezentate aspectele clinice şi dermatoscopice care au stat la baza diagnosticării a trei leziuni pigmentate verucoase cutanate. Influența datelor clinice asupra interpretării parametrilor dermatoscopici este un fapt incontestabil, fapt observat şi în cele două cazuri de keratoză seboreică prezentate, ambele încadrate eronat ca leziuni melanocitare (nev verucos, respectiv melanom). In primul caz prezentat, vârsta pacientei și aprecierea inexactă a duratei de evoluție au condus spre diagnosticul de nev verucos, deși parametrii dermatoscopici erau specifici keratozei seboreice. In al doilea caz de keratoză seboreică confirmată histopatologic, amplitudinea aspectelor clinice de melanom au făcut ca examinatorul să identifice parametrii dermatoscopici compatibili cu diagnosticul de melanom, ignorându-i pe cei specifici keratozei seboreice. Cazul de melanom prezentat în acest articol clinic a mimat o keratoză seboreică, iar imaginea dermatoscopică a prezentat doar trăsături subtile specifice melanomului. In toate cele trei cazuri prezentate dermatoscopia a identificat leziunile ca posibil maligne şi a impus biopsia excizională pentru precizarea diagnosticului şi alegerea conduitei terapeutice adecvate.

Correspondence to: Virginia Chițu, "Colentina” University Hospital, First Department of Dermatology, 19-21 Ştefan cel Mare Str., sector 2, 020125, Bucharest, Romania Tel. +40213173245 , Fax +40213165512

E-mail: virginiachitu@gmail.com

\section{REFERENCES}

1. KITTLER H, ROSENDAHL C, CAMERON A, TSCHANDL P. Dermatoscopy.Facultas Verlags and Buchhandels. Vienna, 2011: 25-129.

2. LONGO C, MOSCARELLA E, PIANA S, LALLAS A, CARRERA C, PELLACANI G, et al. Not all lesions with a verrucous surface are seborrheic keratoses. J Am Acad Dermatol. 2014; 70(6):e121-3.

3. ARGENZIANO G, ZALAUDEK I, FERRARA G, JOHR R, LANGFORD D, et al. Dermoscopy features of melanoma incognito: indications for biopsy. J Am Acad Dermatol. 2007; 56(3):508-13.

4. TEIXEIRA V, SERRA D, VIEIRA R, FIGUEIREDO A, JOSÉ JULIÃO M.J. Melanoma: when dermoscopy is a pitfall. International Journal of Dermatology. 2014; 53(4): 397-524, e240-e316.

5. YOSHIMI N, IMAI Y, KAKUNO A, TSUBURA A, YAMANISHI K, KUROKAWA I. Epithelial keratin and filaggrin expression in seborrheic keratosis: evaluation based on histopathological classification. International Journal of Dermatology, 2014; 53(6):707-13.

6. THOMAS VD, SNAVELY NR, LEE KK, SWANSON NA. Benign Epithelial Tumors, Hamartomas, and Hyperplasias. In: Fitzpatrick's Dermatology in General Medicine, $8^{\text {th }}$ edition, McGraw-Hill Medical, 2012: 1319-23.

7. STRICKLIN SM, STOECKER WV, OLIVIERO MC, RABINOVITZ HS, MAHAJAN SK. Cloudy and starry milia-like cysts: how well do they distinguish seborrheic keratoses from malignant melanomas?. J Eur Acad Dermatol Venereol. 2011; 25(10):1222-4. 
8. AOYAGI S, HATA H, IZUMI K, IITANI MM, SHIMIZU H. Diagnostic pitfalls of using dermoscopic features to differentiate between malignant melanoma and pigmented seborrhoeic keratosis. Acta Derm Venereol. 2010; 90(4):440-1.

9. JAMES W.D, BERGER T.G, ELSTON D.M. Andrews'diseases of the skin clinical dermatology. $11^{\text {th }}$ Saunders Elsevier. 2011 : 625-26.

10. RICOTTI C, CATHER J, COCKERELL C.J. Pathology of melanoma: interpretation and new concepts. In: Cancer of the Skin; $2^{\text {nd }}$, Elsevier, 2011: 295-317.

11. WANG S.Q, OLIVIERO M.C, RABINOVITZ H.S. The dermoscopic patterns of melanoma and non-melanoma skin cancer. In: Cancer of the Skin; $2^{\text {nd }}$, Elsevier, 2011:386-399.

12. DE GIORGI V, GRAZZINI M, SAVARESE I, ROSSARI S, GORI A, MASSI D, et al. What can hide under exophytic verrucous appearance? Acta Derm Venereol. 2011; 91(1):100-1.

13. THOMAS I, KIHICZAK NI, ROTHENBERG J, AHMED S, SCHWARTZ RA. Melanoma within the seborrheic keratosis. Dermatol Surg. 2004; 30 (4 Pt 1): 559-61.

14. FEINSILBER D, KOGAN N, ROSATI O.M, CORBELLA C, SCHROH R, CALB I. Verrucous melanoma: differences and similarities between primary and secondary form. Dermatología Argentina, 2009; 15(2):35-38.

Received June 23, 2015 